LINGUA, Vol. 16, No. 1, Maret 2019

p ISSN: 1979 9411; e ISSN: 2442 238X

Http://lingua.pusatbahasa.or.id; Email: presslingua@gmail.com

Center of Language and Cultural Studies, Surakarta, Indonesia

Sujito, Mujiono \& Muttaqin, Mahir Wildan. 2019. Pengaruh Teknik Comprehensive Modelling

terhadap Mutu Linguistis, Retorika, dan Mekanis pada Artikel Jurnal Penelitian Mahasiswa.

Lingua (2019), 16(1): 37 46. DOI: 10.30957/lingua.v16i1.573.

\title{
PENGARUH TENIK COMPREHENSIVE MODELLING TERHADAP MUTU LINGUISTIS, RETORIKA DAN MEKANIS PADA ARTIKEL JURNAL PENELITIAN MAHASISWA
}

\author{
Sujito $^{1}$, Mujiono ${ }^{2}$ \& Wildan Mahir Muttaqin ${ }^{3}$ \\ 1,3 Pendidikan Bahasa Inggris, IAIN Surakarta, \\ ${ }^{2}$ Pendidikan Bahasa Inggris, Universitas Kanjuruhan Malang \\ Corresponding author: sujitodoktor@gmail.com
}

\begin{abstract}
This study was intended to test the differences between the students who were given comprehensive modeling and those who are not given comprehensive modeling concerning with their achievement of Scientific Journal Writing in English Educational Department of IAIN Surakarta. The sample consists of 34 students randomly selected from the population. Data were collected by administering writing test and analyzed by correlated sample t-test. The result revealed that there was significant difference between students who were given comprehensive modeling and those who were not given comprehensive modeling in their achievement of Scientific Journal Writing in English Educational Department of IAIN Surakarta. It was derived that $p=.000>.005$. So, the alternate hypothesis stating that the EFL students who were given comprehensive modeling have higher achievement in Scientific Journal Writing than those given conventional method was accepted. It means that the comprehensive modeling is effective way to develop students' achievement in Scientific Journal Writing in English Educational Department of IAIN Surakarta.
\end{abstract}

Keywords - comprehensive writing; writing achievement

DOI: 10.30957/lingua.v16i1.573.

\section{LATAR BELAKANG}

Menulis sebagai salah satu dari empat keterampilan dalam pembelajaran bahasa Inggris mendapat perhatian besar dari banyak ilmuwan linguistik karena karakteristiknya yang menantang dan rumit. Menulis, di antara empat kemampuan bahasa Inggris lainnya memiliki karakteristik tersendiri. Di bidang belajar bahasa Inggris sebagai bahasa asing (EFL) dan bahasa Inggris sebagai bahasa kedua (ESL) di mana empat keterampilan dasar yang umum; Mendengarkan, berbicara, membaca dan menulis diperlukan agar mahasiswa bisa menguasai, menulis dianggap keterampilan yang paling sulit bahkan paling rumit 
LINGUA, Vol. 16, No. 1, Maret 2019

p ISSN: 1979 9411; e ISSN: 2442 238X

Http://lingua.pusatbahasa.or.id; Email: presslingua@gmail.com

Center of Language and Cultural Studies, Surakarta, Indonesia

Sujito, Mujiono \& Muttaqin, Mahir Wildan. 2019. Pengaruh Teknik Comprehensive Modelling

terhadap Mutu Linguistis, Retorika, dan Mekanis pada Artikel Jurnal Penelitian Mahasiswa.

Lingua (2019), 16(1): 37 46. DOI: 10.30957/lingua.v16i1.573.

sekalipun. Keterampilan menulis adalah kompleks dan terkadang sulit untuk diajar, yang membutuhkan penguasaan perangkat gramatikal dan retorika juga elemen konseptual (Heaton (1989); Latief (1990); Sujito and Widjajanti (2017); Sun (2009); Sholikhah (2017). Para mahasiswa dan Dosen EFL/ESL telah lama mengakui bahwa belajar menulis dalam bahasa Inggris adalah proses yang kompleks.

Penulisan argumentasi dalam setting akademik memerlukan penulisan khusus berdasarkan objektivitas, netralitas, dan observasi. Objektivitas berarti bahwa siapa pun yang menggunakan metodologi yang sama dan data yang sama harus memiliki harapan yang masuk akal untuk mencapai kesimpulan yang sama. Kesimpulan yang diambil dari data harus ditunjukkan dengan jelas beserta datanya. Netralitas mengharuskan seorang penulis untuk mempertimbangkan semua data yang relevan dan bersedia untuk memodifikasi atau menolak tesisnya jika terbukti tidak dapat dipercaya. Data penulisan jurnal ilmiah adalah setting akademik yang dikumpulkan melalui observasi dan digunakan untuk menyusun tesis. Akibatnya, penulisan akademis terutama bersifat denotatif dan faktual (Winkler dan McCuen, 1974:295).

Dari segi bahasa, penulis harus memiliki gayanya sendiri, yaitu seperangkat karakteristik yang umumnya ditemukan dalam penulisan seorang penulis. Gaya tersebut diwujudkan dalam penggunaan tiga unsur terpenting penulisan formal: tone, struktur kalimat, dan diksi (Hogins dan Lillard, 1972:16). Tone adalah adalah sikap penulis terhadap subjek atau subjeknya dengan memilih kata-kata, pilihan struktur gramatikal, dan bahkan dengan panjang kalimat. Kertas akademis berisi lebih banyak bentuk kata kerja pasif dan kosa kata teknis. Ini harus memiliki tone formal dan impersonal (Oshima and Hogue, 1991:2).

Struktur kalimat menunjukkan preferensi penulis dalam menggunakan jenis kalimat tertentu. Dalam penulisan akademis, struktur kalimatnya umumnya panjang dan kompleks; tidak terbatas pada pada kosa kata sederhana. Ini menghindari bahasa gaul dan kontraksi dan penggunaan tata bahasa yang umumnya diabaikan (Hogins dan Lillard, 1972:16).

Kalimat panjang dan tipe kalimat juga merupakan faktor yang menentukan tingkat dan daya tarik penulisan jurnal ilmiah. Panjang kalimat mengacu pada jumlah kata per kalimat; Tipe kalimat mengacu pada struktur kalimat, yaitu sederhana, majemuk, kompleks. Umumnya, pendek, kalimat sederhana lebih mudah dipahami daripada yang lebih lama. Namun, kata-kata yang panjang dan kompleks terkadang terkait dengan materi yang penting dan canggih. Terkadang kata-kata seperti itu diperlukan untuk menyampaikan makna yang tepat kepada khalayak yang spesifik (Carosso dan Standford, 1983:92-93). Selain itu, tulisan formal umumnya memasukkan kata ganti relatif (yang, yang, siapa) yang hampir selalu diabaikan dalam pidato (Hogins dan Lillard, 1972:16).

Unsur penting lainnya dari penulisan jurnal ilmiah adalah diksi, jenis kata yang digunakan. Dengan cara bahwa gaya tertentu tidak sesuai dalam situasi tertentu, kata-kata individual sesuai penggunaannya (Hogins dan Lillard, 1972:16). Dalam semua tulisan, kosa 
LINGUA, Vol. 16, No. 1, Maret 2019

p ISSN: 1979 9411; e ISSN: 2442 238X

Http://lingua.pusatbahasa.or.id; Email: presslingua@gmail.com

Center of Language and Cultural Studies, Surakarta, Indonesia

Sujito, Mujiono \& Muttaqin, Mahir Wildan. 2019. Pengaruh Teknik Comprehensive Modelling

terhadap Mutu Linguistis, Retorika, dan Mekanis pada Artikel Jurnal Penelitian Mahasiswa.

Lingua (2019), 16(1): 37 46. DOI: 10.30957/lingua.v16i1.573.

kata langsung dan tidak ambigu sangat efektif. Bagi khalayak umum, kata-kata yang mudah dan jelas adalah yang terbaik (Carosso dan Standford, 1983:92).

Singkatnya, penulisan jurnal ilmiah yang baik membutuhkan tata bahasa dan organisasi yang baik. Penggunaan bahasa penulisan akademis bersifat formal. Informasi dan gagasan dalam penulisan akademik dinyatakan dalam bahasa formal dengan tipe atau retorika tertentu. Fitur gramatikal dari penulisan akademis harus memenuhi fungsi retoris seperti pelengkap verbal, nominalization, penggunaan artikel yang pasti dan tidak pasti, klausa relatif, tenses, perjanjian kata kerja, dan perangkat kohesif seperti pengulangan leksikal, pronoun referensial, konjungsi, sinonim Dan frase tersubstitusi (Halliday dan Hasan, 1976). Penggunaan struktur kalimat yang tepat, kosa kata yang tepat, dan retorika yang tepat membantu pembaca mengidentifikasi proposisi dalam teks lebih mudah (Richards, 1992:103).

Bahasa penulisan jurnal ilmiah dalam setting akademik menggunakan simbol khusus yang menggambarkan fitur kosa kata, tata bahasa, dan retorika. Pernyataan tersebut dijelaskan secara akurat. Penggunaan struktur kalimat yang tepat, kosa kata yang tepat, dan retorika yang tepat membantu pembaca mengidentifikasi proposisi dalam teks lebih mudah (Richards, 1992:103).

Kemampuan fitur linguistik dalam penulisan jurnal ilmiah untuk mahasiswa jelas dan ini menunjukkan seberapa baik penulis mampu mengembangkan gagasan dan tata bahasa yang baik. Sebaliknya, demonstrasi linguistik yang belum matang dalam tulisan akan menghasilkan kalimat canggung dan tulisan yang buruk. Fitur linguistik secara tertulis meliputi empat jenis: sintaks, tatabahasa, kosakata, dan mekanika.

Proses belajar mengajar membutuhkan media pembelajaran yang sesuai dan menantang untuk menyampaikan materi pengajaran kepada siswa. Media pembelajaran memiliki fungsi yang signifikan untuk keberhasilan proses belajar mengajar. Media pembelajaran membantu mempengaruhi keberhasilan guru dalam mentransfer pengetahuan kepada siswa dengan menarik motivasi dan minat siswa (Sujito et al. 2018). Isu tentang pengajaran menulis di ELT selalu menarik untuk diteliti. Menulis sebagai salah satu dari empat keterampilan dalam pembelajaran bahasa adalah spesifik dan mengajarkannya juga menantang. Banyak upaya telah dilakukan dengan susah payah oleh para ahli bahasa dan praktisi ELT untuk mencapai hasil akhir dari pengajaran menulis. Tulisan itu adalah keterampilan yang paling banyak dikuasai pembelajar L2 sudah jelas karena keterampilan yang terlibat dalam penulisan sangat kompleks. Mengajar kursus secara tertulis adalah tugas yang sulit bahkan menantang. Teori yang harus disadari dan faktor yang harus diperhatikan adalah sebanyak masalah yang harus dihadapi. Richard dan Renandya (2002) menyatakan bahwa merencanakan dan mengajar secara tertulis bisa menjadi tugas yang menakutkan.

Hedge (2003) menyatakan bahwa pengajaran menulis comprehensive modelling atau pendekatan berbasis teks dalam penulisan adalah semacam orientasi dalam pengajaran menulis yang berfokus pada perhatian mahasiswa terhadap fitur teks dan sebagian besar 
LINGUA, Vol. 16, No. 1, Maret 2019

p ISSN: 1979 9411; e ISSN: 2442 238X

Http://lingua.pusatbahasa.or.id; Email: presslingua@gmail.com

Center of Language and Cultural Studies, Surakarta, Indonesia

Sujito, Mujiono \& Muttaqin, Mahir Wildan. 2019. Pengaruh Teknik Comprehensive Modelling

terhadap Mutu Linguistis, Retorika, dan Mekanis pada Artikel Jurnal Penelitian Mahasiswa.

Lingua (2019), 16(1): 37 46. DOI: 10.30957/lingua.v16i1.573.

berkaitan dengan pengembangan kemampuan mahasiswa untuk menghasilkan fitur tersebut secara akurat. Dalam pengajaran menulis menggunakan comprehensive modelling, ditempatkan pada "model" menulis yang akan ditiru para mahasiswa dan seberapa baik hasil akhir mahasiswa diukur terhadap daftar kriteria yang mencakup konten, organisasi, penggunaan kosa kata, tata bahasa Penggunaan dan pertimbangan mekanis seperti ejaan dan tanda baca (Segal dan Pavlik, 1985; Reid 1988; Brown, 2001). Kerugian dari pendekatan ini karena beberapa ahli menyatakan bahwa pendekatan ini gagal untuk mengenali bahwa orang menulis untuk audiens dan untuk suatu tujuan dan gagasan yang dibuat dan dirumuskan selama proses penulisan.

Metode pengajaran comprehensive modelling secara tertulis melibatkan analisis teks model untuk meningkatkan kesadaran tentang bagaimana strukturnya disusun. Ini juga melibatkan praktik formal dari fitur semacam itu sebagai penggunaan pasif dalam deskripsi proses, penggunaan klausa relatif dalam deskripsi orang, tempat, sistem dan penggunaan adverbial waktu dalam catatan sejarah mengenai perkembangan definisi paragraf. Praktik ini bersifat terkendali dan seringkali ada sedikit kesempatan untuk menulis. Peran dosen adalah untuk mengarahkan pada menulis "prima" melalui kegiatan persiapan dan untuk mengevaluasinya setelah diproduksi untuk mendiagnosis kekuatan dan kelemahan.

Fakta bahwa mahasiswa EFL di perguruan tinggi di Indonesia masih mendapatkan kesulitan untuk mendapatkan prestasi akademik yang tinggi, terungkap oleh banyak data empiris. Berbagai bukti menunjukkan bahwa mahasiswa EFL masih menghadapi masalah dalam membuat menulis dalam setting akademik, entah itu aspek linguistik atau aspek retorika. Temuan berbagai penelitian menunjukkan bahwa subjek penulisan belum ditangani secara tepat. Di Indonesia, menulis bukanlah hal favorit untuk diajarkan, karena pengajaran menulis membutuhkan lebih banyak waktu daripada mengajar subjek lain. Akibatnya, sangat sedikit Dosen yang tertarik untuk mengajar menulis, dan bahkan lebih sedikit dari mereka yang tertarik untuk melakukan penelitian mengenai hal ini (Latief, 1990).

Tujuan penelitian/target temuan penelitian ini adalah: Untuk membuktikan secara empiris pengaruh penerapan Comprehensif Modelling terhadap mutu linguistis (penggunaan kosakata, kebenaran tata bahasa/language use dan penggunaan mekanika bahasa) penulisan jurnal penelitian pada mahasiswa semester 6 PBI IAIN Surakarta.

Hasil penelitian ini diharapkan dapat digunakan sebagai salah satu referensi pengembangan konsep teori yang berkaitaan dengan pengajaran menulis untuk mahasiswa Pendidikan Bahasa Inggris. Lebih lanjut penelitian ini diharapkan mampu memperkaya teori pengajaran menulis di tingkat pendidikan tinggi yang dikaitkan dengan kondisi mahasiswanya. Hasil penelitian ini diharapkan mampu secara teoritis menjawab keraguan antara pentingnya pengajaran yang berorientasi proses dan produk dengan menegaskan bahwa penggabungan dari keduanya dalam bentuk teknik Comprehensif Modelling mampu lebih bagus dalam meningkatkan mutu penulisan jurnal ilmiah oleh mahasiswa. 
LINGUA, Vol. 16, No. 1, Maret 2019

p ISSN: 1979 9411; e ISSN: 2442 238X

Http://lingua.pusatbahasa.or.id; Email: presslingua@gmail.com

Center of Language and Cultural Studies, Surakarta, Indonesia

Sujito, Mujiono \& Muttaqin, Mahir Wildan. 2019. Pengaruh Teknik Comprehensive Modelling

terhadap Mutu Linguistis, Retorika, dan Mekanis pada Artikel Jurnal Penelitian Mahasiswa.

Lingua (2019), 16(1): 37 46. DOI: 10.30957/lingua.v16i1.573.

Secara praktis hasil penelitian ini diharapkan dapat memberikan kontribusi informative kepada para dosen mata kuliah menulis di tingkat pendidikan tinggi dan juga kepada perancang kurikulum di tingkat pendidikan tinggi. Secara empiris hasil penelitian bisa dijadikan sebagai sebuah sarana untuk memberikan contoh pengajaran menulis dengan teknik yang efektif.

\section{METODE}

Pengujian terhadap keefektifan Comprehensive Modelling dilakukan dengan membandingkan antara bahan ajar matakuliah Scientific Journal Writing Comprehensive Modelling dengan yang tidak menggunakan Comprehensive Modelling melalui eksperimen. Pengujian dilakukan pada kelompok subjek penelitian yang secara teoritis dikategorikan setara dan homogen. Perlakuan pada masing-masing kelompok dilakukan secara simultan.

Pembuktian Hipotesis dilakukan dengan independent sample $t$ test. Uji $t$ ini di gunakan untuk mengetahui apakah ada perbedaan tingkat efektifitas pembelajaran matakuliah Reseach mahasiswa semester $\mathrm{V}$ program studi pendidikan Bahasa Inggris antara produk bahan ajar Research dengan buku teks dengan hasil produk bahan ajar matakuliah Research dengan Comprehensive Modelling. Metode analisis statistik yang digunakan dalam penelitian ini dengan analisis SPSS for Windows.16.0 (Paired Sample Test) (Uyanto, 2009:134).

Adapun rumusan hypothesisnya adalah (1) $\mathrm{H}_{\mathrm{o}}: \mu_{1} \leq \mu_{2}$ artinya rata-rata $\mathrm{X}_{1}$ lebih kecil atau sama dengan rata-rata $X_{2} ;(2) H_{1}: \mu 1 \geq \mu 2$ artinya rata-rata $X_{1}$ lebih besar atau sama dengan rata-rata $\mathrm{X}_{2}$.

Pembuktian hipotesis dengan membandingkan $t$ hitung dengan $t$ tabel. Jika $t$ hitung $<\mathrm{t}$ tabel maka Ho diterima artinya tingkat efektifitas bahan ajar dengan buku teks lebih besar dari setelah adanya pengembangan model bahan ajar matakuliah Scientific Journal Writing dengan Comprehensive Modelling pada mahasiswa semester V. Jika $t$ hitung $>t$ tabel maka Ho ditolak artinya tingkat efektifitas pengembangan model bahan ajar matakuliah Scientific Journal Writing dengan Comprehensive Modelling pada mahasiswa semester V lebih besar dari bahan ajar matakuliah Scientific Journal Writing dengan buku teks writing biasa. Jika analisis menggunakan program SPSS, maka signifikan yang di terima apabila sig-nifikannya di bawah 0.05 .

\section{HASIL}

Hasil analisis diskriptif pada kelompok eksperimen dan kelompok control di lihat pada table 1 . 
LINGUA, Vol. 16, No. 1, Maret 2019

p ISSN: 1979 9411; e ISSN: 2442 238X

Http://lingua.pusatbahasa.or.id; Email: presslingua@gmail.com

Center of Language and Cultural Studies, Surakarta, Indonesia

Sujito, Mujiono \& Muttaqin, Mahir Wildan. 2019. Pengaruh Teknik Comprehensive Modelling terhadap Mutu Linguistis, Retorika, dan Mekanis pada Artikel Jurnal Penelitian Mahasiswa.

Lingua (2019), 16(1): 37 46. DOI: 10.30957/lingua.v16i1.573.

Tabel 1. Hasil Analisis Diskrptif

\begin{tabular}{lccccccc}
\hline Kelompok & $\mathrm{N}$ & Range & Minimum & Maximum & Mean & $\begin{array}{l}\text { Standar } \\
\text { Deviasi }\end{array}$ & Variance \\
\hline $\begin{array}{l}\text { Kelompok } \\
\text { eksperimen }\end{array}$ & 33 & 25.00 & 66.00 & 92.00 & 80.5292 & 8.57137 & 73.467 \\
$\begin{array}{l}\text { Kelompok } \\
\text { kontrol }\end{array}$ & 33 & 34.00 & 56.00 & 91.00 & 71.2942 & 9.26229 & 85.795 \\
\hline
\end{tabular}

Berdasarkan hasil analisis diskriptif data penelitian pada kelompok eksperimen dapat diketahui bahwa, nilai rata-rata mata kuliah Introduction to Educational Research Method lebih tinggi dibandingkan dengan nilai rata-rata pada kelompok kontrol. Rata-rata nilai kelompok eksperimen adalah 80.5294; nilai terendah $=65.00$ dan tertinggi 91,00; dan $\mathrm{SD}=8.57139$. Sedangkan pada kelompok kontrol nilai rata-ratanya 71.2941 dengan nilai terendah $=55.00$ dan tertinggi $=90.00$ dan $\mathrm{SD}=9.26227$.

Sebelum data dianalisis menggunakan independent sample t-test terlebih dahulu diuji normalitas dan homogenitasnya. Hasil uji normalitas dengan menggunakan Kolmogorov-Smirnov diperoleh nilai $\mathrm{p}=0.058$, Asymp.Sig. (2-tailed) $=0,058$. Karena nilai $\mathrm{p}>0,05$, maka dapat diketahui bahwa, data normal. Sedangkan hasil uji homogenitas varian diperoleh angka signifikansi untuk probabilitas Base on Mean $=.269$, Based on Median $=.617$, Based on Median and with adjusted $\mathrm{df}=.617$, dan Based on Trimmed Mean $=.284$. Oleh karena $\mathrm{p}>0,05$, maka data memiliki varian yang homogen. Dengan demikian, data dalam penelitian ini te16.h memenuhi uji prasyarat analisis. Selanjutnya data dianalisis menggunakan independent sample t-test. Hasill analisisnya dapat dilihat pada tabel 2 .

Tabel 2. Independent Samples Test

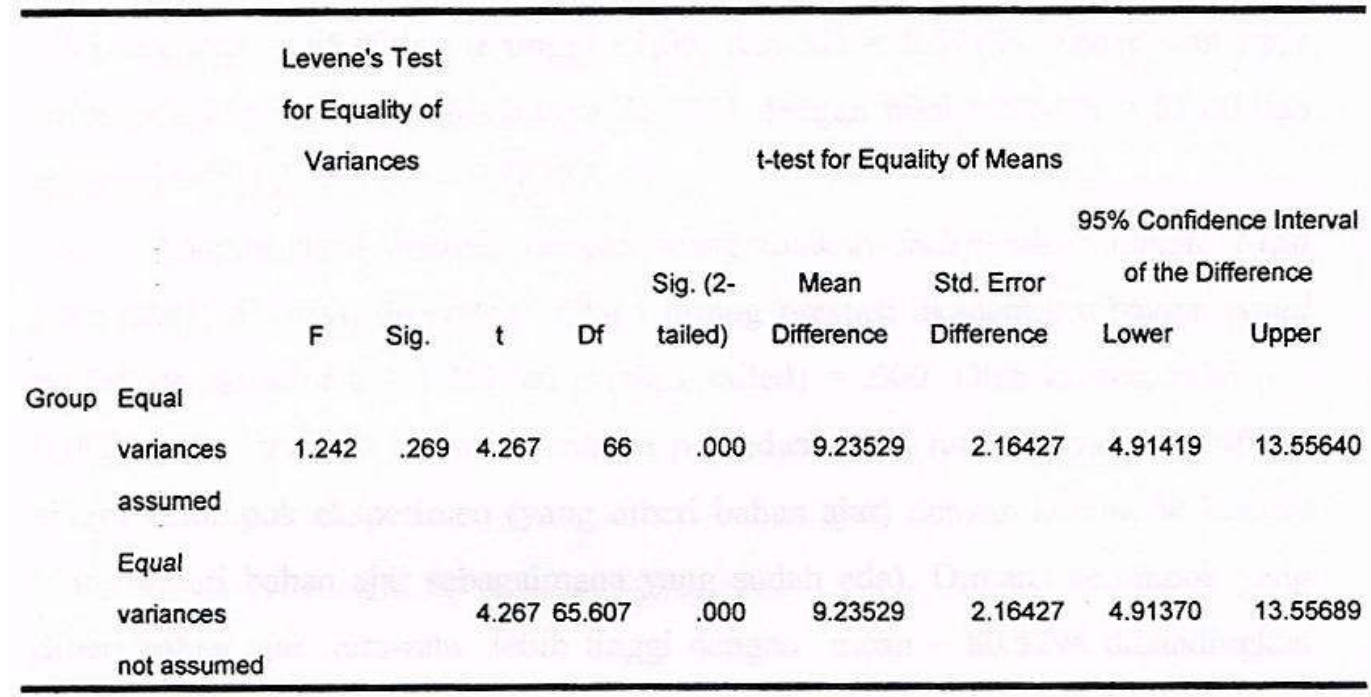


LINGUA, Vol. 16, No. 1, Maret 2019

p ISSN: 1979 9411; e ISSN: 2442 238X

Http://lingua.pusatbahasa.or.id; Email: presslingua@gmail.com

Center of Language and Cultural Studies, Surakarta, Indonesia

Sujito, Mujiono \& Muttaqin, Mahir Wildan. 2019. Pengaruh Teknik Comprehensive Modelling

terhadap Mutu Linguistis, Retorika, dan Mekanis pada Artikel Jurnal Penelitian Mahasiswa.

Lingua (2019), 16(1): 37 46. DOI: 10.30957/lingua.v16i1.573.

Berdasarkan hasil analisis dengan menggunakan Independent sample t-test pada tabel di atas, diperoleh nilai t hitung prestasi akademik dibagian equal variances assumed $\mathrm{t}$ $=4.267 \mathrm{dan} \mathrm{p}($ sig. 2 tailed $)=.000$. Oleh karena, nilai $\mathrm{p}<0,005$, maka terbukti bahwa, terdapat perbedaan nilai rata-rata yang signifikan antara kelompok eksperimen (yang diberi bahan ajar) dengan kelompok kontrol (yang diberi bahan ajar sebagaimana yang sudah ada). Dimana kelompok yang diberi bahan ajar rata-rata lebih tinggi dengan mean $=$ 80.5294 dibandingkan kelompok yang tidak diberi dengan mean $=71.2941$. Dengan demikian, maka hipotesis alternative dalam penelitian ini yang berbunyi; "Kelompok yang diberi model pengembangan bahan ajar Scientific Journal Writing dengan comprehensive writing memiliki nilai rata-rata lebih tinggi dibandingkan kelompok yang tidak diberi model pengembangan bahan ajar Scientific Journal Writing dengan comprehensive writing. Oleh karena itu model pengembangan bahan ajar Intro to Educational Research dengan comprehensive writing effektif digunakan oleh mahasiswa semester $\mathrm{V}$ program studi pendidikan bahasa Inggris di Universitas Kanjuruhan Malang.

\section{PEMBAHASAN}

Berdasarkan hasil analisis diskriptif data penelitian pada kelompok eksperimen dapat diketahui bahwa, nilai rata-rata mata kuliah Introduction to Educational Research Method lebih tinggi dibandingkan dengan nilai rata-rata pada kelompok kontrol. Rata-rata nilai kelompok eksperimen adalah 80.5294; nilai terendah $=65.00$ dan tertinggi 91,00; dan $\mathrm{SD}=8.57139$. Sedangkan pada kelompok kontrol nilai rata-ratanya 71.2941 dengan nilai terendah $=55.00$ dan tertinggi $=90.00$ dan $\mathrm{SD}=9.26227$.

Adapun hasil analisis dengan menggtmakan Independent sample t-test pada tabel di atas, diperoleh nilai $\mathrm{t}$ hitung prestasi akademik dibagian equal variances assumed $\mathrm{t}=$ 4.267dan p $(\operatorname{sig} .2$ tailed $)=.000$. Oleh karena, nilai $\mathrm{p}<0,005$, maka terbukti bahwa, terdapat perbedaan nilai rata-rata yang signifikan antara kelompok eksperimen (yang diberi bahan ajar) dengan kelompok kontrol (yang diberi bahan ajar sebagaimana yang sudah ada). Dimana kelompok yang diberi bahan ajar rata-rata lebih tinggi dengan mean = 80.5294 dibandingkan kelompok yang tidak diberi dengan mean $=71.2941$. Dengan demikian, maka hipotesis alternative dalam penelitian ini yang berbunyi; "kelompok yang diberi model pengembangan bahan ajar Scientific Journal Writing dengan comprehensive writing memiliki nilai rata-rata lebih tinggi dibandingkan kelompok yang tidak diberi model pengembangan bahan ajar Scientific Journal Writing dengan comprehensive writing. Oleh karena itu model pengembangan bahan ajar Intro to Educational Research dengan comprehensive writing effektif digunakan oleh mahasiswa semester VI program studi pendidikan bahasa Inggris di IAIN SURAKARTA.

Dengan demikian penggunaan bahan ajar dengan comprehensive writing dapat meningkatkan hasil belajar, maka comprehensive writing berpengaruh terhadap hasil belajar Scientific Journal Writing Hal ini dapat dimaklumi karena penyajian materi lebih sistematis, mahasiswa lebih mudah mengingat konsep karena dalam penyampaian materi 
LINGUA, Vol. 16, No. 1, Maret 2019

p ISSN: 1979 9411; e ISSN: 2442 238X

Http://lingua.pusatbahasa.or.id; Email: presslingua@gmail.com

Center of Language and Cultural Studies, Surakarta, Indonesia

Sujito, Mujiono \& Muttaqin, Mahir Wildan. 2019. Pengaruh Teknik Comprehensive Modelling

terhadap Mutu Linguistis, Retorika, dan Mekanis pada Artikel Jurnal Penelitian Mahasiswa.

Lingua (2019), 16(1): 37 46. DOI: 10.30957/lingua.v16i1.573.

diberikan analogi sehingga lebih konkrit, mahasiswa juga dapat memahami suatu konsep lebih mendalam karena konsep yang diterima dikaitkan dengan konsep lain yang terkait dan mahasiswa lebih mudah mengingat informasi barn yang disampaikan dosen. Beberapa peneliti membuktikan keefektifan pembelajaran comprehensive writing seperti Hanclosky membuktikan bahwa teori comprehensive writing lebih unggul bila dibandingkan dengan advance organizer dan analisis tugas dalam belajar konsep dan prinsip. Nyoto (1999) juga membuktikan bahwa comprehensive writing lebih unggul dibandingkan dengan gaya kognitif dan locus of control. Hal ini didukung oleh penelitian Suprianto (2002) yang menunjukkan bahwa penerapan comprehensive writing mempunyai pengaruh yang signifikan dalam meningkatkan prestasi belajar bila dibandingkan dengan pembelajaran konvensional.

Hasil penelitian lain menunjukkan bahwa hasil pembelajaran dengan comprehensive writing lebih tinggi dibandingkan dengan menggunakan buku teks biasa. Yaitu mahasiswa yang diajar dengan comprehensive writing mendapat perolehan skor rata-rata 63,13, sedangkan mahasiswa yang diajar dengan menggunakan buku text teks menunjukkan rerata nilai 57,97. Ini sejalan dengan penelitian yang dilakukan oleh Ardian (2008) yang menunjukkan bahwa siswa yang diberikan perlakuan pembelajaran elaborasi mendapat nilai rata-rata $(85,15)$, sedangkan yang diberikan pembelajaran model konvensional mendapat nilai rata-rata $(75,30)$. Karena pembelajaran model elaborasi dan comprehensive writing sangat berkaitan erat. Dari hasil penelitian tersebut di atas menunjukkan bahwa comprehensive writing masih lebih unggul dibanding dengan model-model yang lain, terutama dengan model buku teks.

Model yang dilakukan pada kelompok kontrol adalah model pembelajaran konvensional. Dalam model ini dosen menjelaskan materi kemudian mahasiswa diberi kesempatan bertanya dan mencatat materi. Model yang dilakukan pada kelompok kontrol sebatas pada penggunaan metode ceramah (lecturing), questioning) dan practice. Dari metode-metode tersebut, metode ceramah yang dominan digunakan untuki menyampaikan mata kuliah Scientific Journal Writing. Sehingga menyebabkan siswa kurang tertarik dalam mengikuti proses belajar mengajar, motivasi belajar mahasiswa kurang, akibatnya mahasiswa kurang suka membaca matari yang ada kaitannya dengan research method, sehingga berakibat rendahnya nilai mahasiswa dalam mata kuliah Scientific Journal Writing.

\section{SIMPULAN DAN SARAN}

Berdasarkan hasil analisis diskriptif data penelitian pada kelompok eksperimen dapat diketahui bahwa, nilai rata-rata mata kuliah Introduction to Educational Research Method lebih tinggi dibandingkan dengan nilai rata-rata pada kelompok kontrol. Rata-rata nilai kelompok eksperimen adalah 80.5294; nilai terendah $=65.00$ dan tertinggi 91,00; dan $\mathrm{SD}=8.57139$. Sedangkan pada kelompok kontrol nilai rata-ratanya 71.2941 dengan nilai terendah $=55.00$ dan tertinggi $=90.00$ dan $\mathrm{SD}=9.26227$. 
LINGUA, Vol. 16, No. 1, Maret 2019

p ISSN: 1979 9411; e ISSN: 2442 238X

Http://lingua.pusatbahasa.or.id; Email: presslingua@gmail.com

Center of Language and Cultural Studies, Surakarta, Indonesia

Sujito, Mujiono \& Muttaqin, Mahir Wildan. 2019. Pengaruh Teknik Comprehensive Modelling

terhadap Mutu Linguistis, Retorika, dan Mekanis pada Artikel Jurnal Penelitian Mahasiswa.

Lingua (2019), 16(1): 37 46. DOI: 10.30957/lingua.v16i1.573.

Berdasarkan hasil analisis dengan menggunakan Independent sample t-test pada tabel di atas, diperoleh nilai t hitung prestasi akademik dibagian equal variances assumed $\mathrm{t}$ $=4.267 \mathrm{dan} \mathrm{p}($ sig. 2 tailed $)=.000$. Oleh karena, nilai $\mathrm{p}<0,005$, maka terbukti bahwa, terdapat perbedaan nilai rata-rata yang signifikan antara kelompok eksperimen (yang diberi bahan ajar) dengan kelompok kontrol (yang diberi bahan ajar sebagaimana yang sudah ada). Dimana kelompok yang diberi bahan ajar rata-rata lebih tinggi dengan mean $=80$ 5294 dibandingkan kelompok yang tidak diberi dengan mean $=71.2941$. Dengan demikian, maka hipotesis alternative dalam penelitian ini yang berbunyi; "kelompok yang diberi model pengembangan bahan ajar Scientific Journal Writing dengan comprehensive writing memiliki nilai rata-rata lebih tinggi dibandingkan kelompok yang tidak diberi model pengembangan bahan ajar Scientific Journal Writing dengan comprehensive writing. Oleh karena itu model pengembangan bahan ajar Intro to Educational Research dengan comprehensive writing effektif digunakan oleh mahasiswa semester $\mathrm{V}$ program studi pendidikan bahasa inggris di IAIN Surakarta.

Berdasarkan hasil penelitian, dikemukakan beberapa saran yang berkaitan dengan usaha penelitian lanjutan (1) Disarankan pada dosen mata kuliah aktif membuat bahan ajar dengan model comprehensive writing yang disesuaikan dengan karakteristik siswa; (2) Kepada peneliti lain disarankan untuk menindak lanjuti penelitian ini yaitu bukan hanya sekedar mengembangkan bahan ajar dengan comprehensive writing pada mata kuliah writing, akan tetapi lebih pada mata kuliah lain yang disesuaikan dengan gaya belajar dan karakteristik mahasiswa; (3) Variabel lain yang dapat diteliti melalui penelitian lanjutan yaitu penelitian research and Development ( $R$ and $D)$.

\section{DAFTAR PUSTAKA}

Ardian. 2008. Pengaruh Strategi Pengorganisasian Elaborasi Dan Gaya Kognitif Spasial Mahasiswa Terhadap Hasil Belajar Gambar Mesin. eprints. uny. ac. id/4697/

Brown, G. and Yule, G. 1981. Discourse Analysis. Cambridge: Cambridge University Press.

Heaton, J,B. 1989. Writing English Language Tests. London: Longman.

Hedge, Tricia. 2003. Teaching and Learning in the Language Classroom. Oxford. University Press.

Hogins, JB and Lillard T. 1972. The Structure of Writing. Rowly, Massachusetts: D.C. Heath and Company.

Latief, M.A. 1990. Assessment of English Writing Skills for Students of English as a Second Language at IKIP MALANG Indonesia. Unpublished Ph.D. Dissertation. Iowa City, Iowa: The University of Iowa.

Oshima, A. and Houge, A. 1991. Writing Academic English: A Writing and Sentence Structure Handbook. Second Edition. Cambridge: Addison-Wesley Publishing Company. 
LINGUA, Vol. 16, No. 1, Maret 2019

p ISSN: 1979 9411; e ISSN: 2442 238X

Http://lingua.pusatbahasa.or.id; Email: presslingua@gmail.com

Center of Language and Cultural Studies, Surakarta, Indonesia

Sujito, Mujiono \& Muttaqin, Mahir Wildan. 2019. Pengaruh Teknik Comprehensive Modelling

terhadap Mutu Linguistis, Retorika, dan Mekanis pada Artikel Jurnal Penelitian Mahasiswa.

Lingua (2019), 16(1): 37 46. DOI: 10.30957/lingua.v16i1.573.

Reid, Joy. 1994. Responding to ESL Students' Text. The Myth of Appropriation. TESOL Quarterly 28 (2): 273-292.

Richard, J.C and Renandya, W.A. 2002. Methodology in Language Teaching. An Anthology of the Current Practice. Cambridge University Press. Cambridge.

Segal, M.S and Pavlik Cheryl. Interaction I, A Writing Process Book. New York. Random House.

Sholikhah, Imroatus. 2017. Drafting and Revising Strategies to Develop English essay by EFL Indonesian Learners. International of Advanced Research. 5 (3). IJAR

Sujito, N. Kurniasih, W.M. Muttaqin, I.N. Sari, A.P. Saleky, P. Tuasikal, Y. Talakua, B.M. Laka, A. Niwele, and F. Aziz. 2018. "Applying ELMS Technology Based Teaching Strategy to Improve Writing Competence for EFL Remedial Students across Different Motivation Level." International Journal of Engineering and Technology(UAE) 7 (3.2 Special Issue 2).

Sujito, Sujito, and Rina Widjajanti. 2017. "Reusing the Product Oriented Writing to Enhance the First Year EFL Undergraduate Field Independent Students' Writing Achievement." In 3rd International Conference on Education and Training (ICET 2017). Atlantis Press. https://doi.org/10.2991/icet-17.2017.18.

Sun, Shunling. 2009. Process Approach to Teaching Writing Applied in Different Teaching Model. English Language Teaching Journal, Vol 2 No.1 2009

Winkler, A.C and McCuen, J.R. 1974. Rhetoric Made Plain. New York: Harcourt Brace Jovanocich, Inc.

Uyanto, S.S. 2009. Pedoman Analisis data dengan SPSS. Yogyakarta: Graha Ilmu. 